8-2004

\title{
Social Divisions and Coercive Control in Advanced Societies: Law Enforcement Strength in Eleven Nations from 1975 to 1994.
}

Stephanie L. Kent

Cleveland State University, s.l.kent59@csuohio.edu

David Jacobs

Ohio State University, JACOBS.184@OSU.EDU

Follow this and additional works at: https://engagedscholarship.csuohio.edu/clsoc_crim_facpub

Part of the Criminology Commons, Social Control, Law, Crime, and Deviance Commons, and the Sociology of Culture Commons

How does access to this work benefit you? Let us know!

\section{Publisher's Statement}

An electronic version of this article is available in JSTOR:http://www.jstor.org/stable/10.1525/ sp.2004.51.3.343 .

\section{Repository Citation}

Kent, Stephanie L. and Jacobs, David, "Social Divisions and Coercive Control in Advanced Societies: Law Enforcement Strength in Eleven Nations from 1975 to 1994." (2004). Sociology \& Criminology Faculty Publications. 111.

https://engagedscholarship.csuohio.edu/clsoc_crim_facpub/111

This Article is brought to you for free and open access by the Sociology \& Criminology Department at EngagedScholarship@CSU. It has been accepted for inclusion in Sociology \& Criminology Faculty Publications by an authorized administrator of EngagedScholarship@CSU. For more information, please contact library.es@csuohio.edu. 


\title{
Social Divisions and Coercive Control in Advanced Societies: \\ Law Enforcement Strength in Eleven Nations from 1975 to 1994
}

\author{
STEPHANIE L. KENT, Ohio State University \\ DAVID JACOBS, Ohio State University
}

\begin{abstract}
Conflict theory suggests that economic stratification poses a threat to order, so we should expect increased inequality to lead to a greater capacity for coercive control. The police are the primary agency that uses force to preserve order, yet we know little about the effects of economic divisions on police size in advanced nations besides the United States. The generality of findings based on a fixed-effects panel design applied to 11 developed nations should provide increased insight about how coercion is used to preserve domestic order. Other social divisions that should matter include minority presence and unemployment. With economic development, urbanism, crime, and social disorganization held constant, economic inequality and crime rates in the last years of the sample matter, but minority presence explains police strength only in the United States. The results suggest that threats to internal stability due to economic stratification are most likely to produce subsequent expansions in formal social control. These findings should help resolve disputes about which potentially destabilizing social divisions provide the most general explanation for shifts in the strength of state agencies that specialize in domestic control.
\end{abstract}

How do advanced states maintain domestic order? One answer hinges on their capacity to employ force. The factors that enhance or reduce the modern state's ability to use coercion to control internal threats have been infrequently studied despite theoretical claims that a capacity for domestic coercion is a prerequisite for internal order (Collins 1975; Goode 1972; Weber 1968). Social order, of course, cannot rest on force alone. Yet even the most benign and progressive rulers must employ at least the threat of violence in order to command resources from unwilling subjects. To provide an unobtrusive domestic control system, modern states avoid the military and use specialized law enforcement agencies, but the distinctive element common to almost all police tasks is coercion (Bittner 1990). In this analysis, we determine whether the potentially destabilizing effects of economic inequality or minority threat produce expansions in the primary agencies that use force to maintain order within advanced nations.

The street-level public officials we study are on "the cutting edge of the state's knife" (Bayley 1985), as the police are the first agency that deals with violent threats when they arise. To retain power, governments must have the ability to employ greater amounts of force than any internal rivals. Effective police agencies are essential even in the most progressive societies because the police are the most proficient and least conspicuous specialists in the daily use of domestic coercion. Cross-national research on the links between the potential 
conflicts based on social divisions and police strength may uncover universal factors that determine the size of these expensive control agencies.

Sociologists often respond to claims about the necessity for force with assertions that a society based only on coercion could not survive. We agree, but we find William Goode's (1972) rejoinder equally persuasive. He argues that scholars often forget that even the worst despots regularly employ means other than coercion or its threat. While no ruler need only use force, it nevertheless is a precondition for order. Subsequent historical illustrations will suggest that alternatives to force quickly become ineffective when the police suddenly become paralyzed. These examples will also suggest that sociologists underestimate the amount of force necessary to maintain order in the most advanced but still unequal societies.

According to many Marxist (Chambliss 1964) and Weberian (Collins 1975) theorists, stability is problematic in even the most progressive societies because resource distributions are skewed so only a few reap lavish rewards. Why are disruptions in domestic order infrequent when so few get so much and so many receive far less? Most sophisticated attempts to explain this paradox do not stress force, but perhaps this obvious alternative should not be completely overlooked. We assess another division that has been largely ignored in comparative studies. Cross-sectional findings suggest that racial threat in U.S. cities is an important explanation for police strength (Jackson 1989; Liska, Lawrence, and Benson 1981). Yet we do not know if minority threat matters beyond the borders of a society that has experienced exceptionally bitter racial conflicts.

Analysts argue that force is important in less-advanced societies. Gerhardt Lenski (1966) claims that state coercion was the primary explanation for inequality in pre-industrial societies. Charles Tilly $(1984,1992)$ shows how the founders of nations relied on violence to subdue internal rivals. Yet the use of domestic coercion is unusual in modern societies with market economies, so we have overlooked this effect. But if state coercion is used to enforce the rules that govern unequal exchanges, coercion becomes the basis of control by rewards (Collins 1975) even if it is inconspicuous. Perhaps those who benefit least from existing arrangements are obedient because they sense it would be foolish to challenge the huge coercive assets of modern states, but that does not make these assets unimportant. We may have been deceived by a domestic tranquility that only seems to be based on consensus. The absence of visible conflict between economic classes may result from passive accommodations to necessity rather than active consent. ${ }^{1}$

Most research addressed these issues by analyzing U.S. data. Colin Loftin and David McDowall (1982) use a time-series approach, and attribute their weak findings to the absence of indicators such as economic inequality and minority presence. Other longitudinal studies (Chamlin 1990; Lizotte, Mercy, and Monkonen 1982; McDowall and Loftin 1986) also find little relationship between crime and police strength, but studies limited to one city forfeit generality. Cross-sectional analyses suggest that racial divisions (Jackson 1989; Jacobs 1979; Liska, Lawrence, and Benson 1981) or economic inequality (Jacobs 1979) explain this

1. Most sociologists think order rests on consent. Polls show that large majorities see social arrangements as just. If such attitudes lead the less affluent who benefit least from existing arrangements to remain passive, the stability of unequal societies is not puzzling. But research suggests that measured attitudes are at best weak causes of behavior (Bertrand and Mullainathan 2001; Tanur 1992). And this causal order may be backwards. If the necessity to conform leads those who have least to avoid the disturbing realization that the existing order is unjust, this consensus explanation would be based on post hoc rationalizations. Successful efforts by the have-nots to alter the existing order are costly and improbable (Olson 1965). Passivity and attitudes that justify passivity may be the best option for those least favored by existing arrangements. If attitudes are not strong causes of behavior or if consensus views are rationalizations for obedience due to the futility of rebellion, an analysis of the links between inequality and domestic coercion may provide new insights about social order. This logic does not mean we need claim that force is the only or even the most important determinant. Findings suggest that confidence in the police is diminished in nations where class distinctions are most pronounced (Cao and Stack 2000). Attempts to study the links between hierarchical divisions and domestic control agencies in the most affluent societies therefore may uncover neglected explanations with considerable explanatory power. 
outcome, but few cross-national studies exist. Ted Gurr (1979) found that police departments expanded despite declining crime rates in the United States and the United Kingdom. David Bayley (1975) analyzed police per kilometer, but this odd measure may explain his weak results. Bayley $(1985,1999)$ later gauged police strength with potentially misleading counts that included military forces with limited or no domestic responsibilities. In part because the few cross-national studies paid little attention to conflict or political explanations, we attempt to fill these gaps in the literature with a superior panel research design.

Prior researchers often had pluralist or consensus assumptions in mind. Pluralists assume there is an impasse in political control over law enforcement because the influence of contending interests is in rough balance (Manly 1983). Consensus theorists claim that citizens agree about how laws should be enforced. Both views imply that inequality will not be related to police strength. Pluralists suggest that those who benefit most from enhanced social control are too divided to realize this goal. Consensus theorists suggest that all classes agree about law enforcement, so hierarchical divisions should be irrelevant. But if the potential conflicts based on hierarchical divisions produce enhanced control capacity, economic inequality or racial-ethnic divisions should explain police strength. Our cross-national approach may provide more definitive findings than prior studies because the fixed-effects panel design we use helps to remove potentially spurious influences, and it helps eliminate the effects of systematic measurement error in the dependent variable. We use extensive controls because we seek to assess the generality of theoretical explanations despite the comparability challenges posed by an analysis of multiple nations.

\section{Theoretical Explanations: Economic Stratification, Minority Presence, and Unemployment as Destabilizing Factors}

\section{Economic Stratification}

According to Anthony Giddens (1971) and Gerhard Lenski (1966), conflict theorists often see economic inequality as a frail condition. William Chambliss and Robert Seidman (1982), for example, claim that "The more economically stratified a society becomes, the more it becomes necessary for dominant groups to enforce through coercion the norms of conduct that guarantee their supremacy" (p. 31). If inequality leads to a potentially unstable social order, this condition should increase requirements for coercion because the threat posed to elites by the "dangerous classes" (Silver 1966) should intensify. Unequal resources also give the affluent the means to increase social control capacity because power is at least partly based on comparative differences in economic resources (Blalock 1967; Collins 1975). If these claims are correct, expansions in economic inequality ought to create additional requirements for social control. And inequality should enhance elite political influence, so the affluent will be more likely to benefit from the greater protections from street crime that will be required after a growth in economic stratification.

Historical accounts support these claims. Alan Silver (1966) writes that the police were developed to protect the "peace loving propertied classes" from the poor. Order had been maintained by either the army or by an irregular force of rural small-property owners called the yeomanry, but the yeomanry often overreacted and they were seen as the direct instrument of elites. The army was equally inappropriate because it was expensive to maintain in the field and poorly equipped to meet daily needs for intermediate measures. Economic elites therefore created a "police system that insulated them from violence, drew attack upon itself, and seemed to separate the 'assertion of constitutional authority' from social and economic dominance" (Silver 1966:37).

These uses persist. Modern departments are reactive with limited capacity to prevent 
street crime (Ericson 1982, 1989; Rubenstein 1973; Wilson 1971). Officers cannot see into buildings and they are not abundant. They must decide who should be stopped on the basis of incongruities (Ericson 1982, 1989; Rubenstein 1973). While departments can control mass violence, these conditions weaken proactive measures against individual crimes (Chevigny 1995). Officers face special difficulties in low-income areas where offenders and the innocent share many characteristics. Yet if the officers are comparatively numerous relative to the population they police, their reliance on anomalies should be more effective in affluent areas where residents tend to be visibly distinct from underclass criminals (Jacobs 1979; Manning 1994). And an ability to contain disorders to poor districts should be enhanced in areas with larger departments because such departments can more effectively insulate affluent neighborhoods from underclass intrusions. Even if the police do not make unwarranted efforts to please the affluent, these citizens will still benefit most from large departments.

These claims about the relationship between department size and differential effectiveness imply that affluent victimization should expand if the police stage unexpected strikes. In $1919,1,500$ officers walked out in Boston, leaving 150 to maintain order (White 1965). After tentative violations in low-income sections that tested department reactions, large crowds looted affluent neighborhoods. In 1969 in Montreal, 3,800 officers went on strike, leaving just 300 on duty (Clark 1975). Again, after tentative beginnings in poor areas, offenses rapidly spread. Bank robberies increased because police response time went from 3 to 30 minutes. After the banks closed, 156 retailers, the most expensive stores, and luxurious hotels were sacked. Other accounts of strikes in Finland, Great Britain, and the United States (Sherman 1992) suggest that after these unanticipated job actions, the negative association between economic status and victimization no longer holds. Findings that larger departments can contain mass violence to the poorest areas (Sherman 1992) also suggest that the prosperous will benefit most from additional police officers.

Theory, historical evidence, and victimization patterns after unanticipated police strikes suggest that we should find a positive relationship between inequality and police strength. Because they can leave or reduce their investments, elected officials who must protect jobs have strong reasons to listen carefully when the affluent lobby for increased police protection (Block 1977; Lindblom 1977). ${ }^{2}$ Information about such covert lobbying or the other intervening political mechanisms that lead to associations between inequality and police strength probably will remain unavailable, but we can test this expectation with circumstantial evidence. To overcome the absence of cross-national findings, we assess the following hypothesis: economic inequality in the most advanced nations will produce subsequent increases in law enforcement strength.

A contingent version of this hypothesis can be tested as well. The effect of class on important outcomes has been sharply disputed. Authors (Bell 1973; Lipset and Clark 1993; Nisbet 1959) have claimed that class and economic differences have become largely irrelevant in post-industrial societies, but such claims have been sharply contested by others (Hout, Brooks, and Manza 1993). Perhaps economic growth and increasing affluence undermined the threat to order due to economic inequality. If this supposition is correct, we can expect that economic inequality will have reduced effects on police strength in the later time periods covered by our sample.

\section{Minority Threat}

Theorists claim that dominant groups are menaced by larger minority populations (Blalock 1967; Blumer 1958). Ethnocentric dominant group beliefs in their superiority and their

2. One objection to this theoretical logic is that it is instrumentalist and unduly simplified. But the structural alternatives to the instrumental approach almost invariably are examples of Marxist functionalism (Stinchcombe 1968) that probably are impossible to refute (Jacobs 1980). A fundamental advantage of the hypothesis we propose is that it is readily amenable to disproof, as there may be no relationship between inequality and police strength. 
tendency to see minorities as alien enhance dominant ethnic group presumptions that they should have automatic rights to the most beneficial statuses and resources. After expansions in their numbers and their potential influence, minority efforts to increase their share of these advantages are contested by dominant groups, but reductions in dominant group influence after a growth in the minority population reduce their ability to resist such threats. One common response is political. To maintain their ascriptive advantages, dominant ethnic or racial groups often successfully lobby for enhanced social controls that target disadvantaged minorities.

Many studies document the links between the size of minority populations and unfavorable attitudes about minorities. Negative views about African Americans in the United States are especially prevalent in areas with the most black residents (Fosset and Kiecolt 1989; Taylor 1998). Additional evidence suggests that these hostile views lead to enhanced demands for repressive criminal measures. With the crime rate held constant, findings show an association between the percentage of African Americans in neighborhoods and fear of crime (Quillian and Pager 2001). Other researchers find increased support for the death penalty in areas with larger African American populations (Baumer, Messner, and Rosenfeld 2003).

After holding the crime rates constant, multiple studies suggest that the threat posed by a large racial or ethnic underclass leads dominant groups to pressure authorities to increase efforts to control street crime. Arrest rates are higher in U.S. cities with higher percentages of black residents (Liska, Chamlin, and Reed 1984). U.S. states with larger minority populations have higher imprisonment rates (Jacobs and Carmichael 2001). A growth in the nonwhite population produces subsequent increases in spending on prisons and jails (Jacobs and Helms 1999). Findings also show that U.S. cities with more substantial minority populations employ more police officers (Jackson 1989; Jacobs 1979; Liska, Lawrence, and Benson 1981), but we have not located any cross-national analyses of this relationship.

On the basis of findings about police strength in U.S. cities, we expect that nations with more substantial minority populations will have comparatively larger police departments. Such accounts suggest that strong relationships between minority threat and police strength should be present in nations like Canada or Australia that have comparatively large minority populations as well (Terrill 1999). We therefore expect that advanced societies with a more substantial minority presence should have larger police departments. But race relations in the United States have been particularly antagonistic (Myrdal 1944; Tocqueville 1948), so findings based on this society may not hold elsewhere. Such an exceptionalism hypothesis can be assessed by testing for an interaction between minority presence in the United States and police strength. If this contingent relationship has explanatory power but minority presence in other nations does not, the findings will suggest that ethnic or racial threat produces more substantial domestic-control capacity only in the nation in the sample that probably has had the worst race relations.

\section{Unemployment}

According to neo-Marxist arguments put forward by Georg Rusche and Otto Kirchheimer (1939) and Chambliss (1964), imprisonment and other repressive measures are used to control jobless populations when labor surpluses expand in market economies. Peter Blau's (1964) claim that exchange imbalances in labor markets may be rebalanced by violence that redistributes resources from the rich to the poor suggests that increased unemployment will sharpen affluent demands for additional police officers. After a growth in joblessness, the prosperous may view the unemployed as a greater threat to order. Enhanced unemployment also may produce increased resentments against underclass street criminals.

Many researchers have assessed the relationship between unemployment and incarcerations, but the results have not been consistent (Parker and Horwitz 1986; Sutton 2004). A review, for example, finds that only about 60 percent of 147 reported relationships between unemployment and imprisonments are positive (Chiricos and Delone 1992). Despite these 
discrepancies, this relationship is plausible. The risks of unemployment are disproportionately born by the least affluent, who have less to lose and more to gain from redistributive violence. Because nations may try to enhance the expected costs of crime during economic downturns, we test the hypothesis that the per capita number of police employees should expand after a growth in unemployment. Disputes about the explanatory power of economic stratification, minority threat, and unemployment remain unresolved, so we test these hypotheses with a cross-national analysis, but other determinants may account for national differences in law enforcement strength.

\section{Alternative Explanations}

David Garland (2000) claims that enhanced demands for law and order result from social disorganization. Some violence that is due to disorganization may not be captured by crime rates, but this violence may lead to public anxieties or resentments and political pressure to hire more officers. Unequal jurisdictions with larger minority populations are likely to place greater emphasis on social control, but this emphasis need not be due to minority or economic threat. Instead, public anxieties based on social disorganization often appear in or near to areas where minority presence and economic stratification are most pronounced. If this effect is not held constant, we could not rule out a claim that this correspondence-rather than minority or economic threat-produces additional police officers. Robert Sampson and his co-authors (Sampson 1987; Sampson and Groves 1989) have reawakened interest in social disorganization by using out-of-wedlock births to gauge this effect, so we analyze this explanatory factor (in analyses not shown, we also assess the effects of infant mortality and divorce rates).

Social control should be difficult in urbanized areas. Serious crime is most prevalent in large cities, probably because anonymity is such a crucial facilitating condition (Jackson 1984), so urbanization is held constant. Research on the determinants of expensive public policies often shows that the tax base is important, so we control for this factor. Finally, serious crime should be held constant because such events are likely to trigger demands for additional officers, but this effect also may be historically contingent. Garland (2001) and others have claimed that street crime has recently became politically salient. Conservative politicians used this wedge issue to divide political coalitions that supported parties on the moderate left, so a stronger relationship between the crime rates and police strength may be present in the last years in the sample.

\section{Research Design and Methods}

\section{Sample}

We test these hypotheses with equivalent information about the number of law enforcement employees. We analyze the following 11 nations because information on shifts in police strength is present: Australia, Belgium, Canada, Denmark, France, the Republic of Ireland, Italy, Norway, Sweden, the United Kingdom, and the United States. ${ }^{3}$ The data we use on the ratio of police employees to national populations include years from 1975 to 1994 in most but not all of these nations. Missing data, the two-year lag on all explanatory variables, and the removal of cases in the first available period to correct for

3. See Terrill (1999), Rounds (2000), and Joutsen (2000) for descriptions of recent police practices in most of these nations. 
serial correlation combine to produce an effective sample of 154 nation-years in all analyses but one. Note that the panel estimators are unbiased even if the number of observations differs between cases (Wooldridge 2002).

\section{Dependent Variable}

We follow past researchers (Jacobs and Helms 1997; Liska, Lawrence, and Benson 1981) and measure police strength with the number of police employees per 100,000 population with data from the UN Surveys of Crime Trends and Criminal Justice Systems. To enhance comparability, these counts were generated using identical instructions. National definitional differences thus may not pose a threat (Maguire and Schulte-Murray 2001), but we also correct this difficulty with statistical remedies. The number of sworn officers is not available, but the more inclusive total employee measure is less likely to contain errors due to employee misclassification, so the more exhaustive measure should best capture effective police strength.

\section{Estimation}

In contrast to the random-effects models used in most panel analyses in sociology, a fixed-effects approach holds constant any unchanging national attributes by entering separate dummy variables for each nation. This makes fixed-effects estimates unbiased if timeinvariant national effects influence the dependent variable, so stronger claims can be made that omitted variable bias is not present (Johnston and DiNardo 1997). These nation-specific dummies used in fixed-effects estimation control for different intercepts for each nation, so these dummy variables will capture national differences in the measurement of law enforcement personnel that may persist despite the standardized instrument used to solicit this data. ${ }^{4}$ Trends in police strength also vary by nation. We remove these potential national differences by entering nation-specific linear trends that will correct for omitted variables or for changes in how police strength is measured. Finally, by including year dummies we control for external shocks like the recession in the 1980s that led to police reductions in multiple nations (Wooldridge [2002] advocates including both case-specific trends and dummies for years; see Papke 1994 or Ziliac and associates 1999 as well). ${ }^{5}$

In contrast to fixed-effects, random-effects estimators do not automatically remove all cross-sectional variation. Although claims that omitted variable bias is not present are less credible, random-effects models capture both cross-sectional and overtime variation. Fixedeffects models may underestimate the explanatory power of variables with greater crosssectional than over-time variation, so we reestimate the best model with random-effects to see if this difficulty is present. Finally, a dependent variable like police per capita changes incrementally, so prior levels of police strength will be strong predictors of current levels.

4. Most fixed-effects routines and the one we use provide a single intercept by reporting a weighted average of the coefficients on the nation-specific dummies, but the coefficients on these dummies nevertheless can be viewed as nation-specific intercepts that remove case-specific constant differences in the dependent variable (Wooldridge 2002).

5. The coefficients on the nation-specific trends represent deviations from the dummy variable controls for aggregate trends (or the year dummies) in police strength that exist across cases (Wooldridge 2002). These nation-specific trends help remove national differences in the amount of influence that explanatory variables have, and thereby make an assumption that these coefficients are constant across nations much more plausible (estimation problems stop us from testing this assumption about constant cross-nation effects with a Hildreth-Houck random coefficients approach). The nation-specific trend variables are included by using separate year count variables for each nation. Note that fixed-effects models can detect a relationship as long as a reasonable degree of over-time variation is present only in some cases (Wooldridge 2002). We nevertheless report a random-effects model that captures cross-sectional as well as over-time effects to see if the fixed-effects results are an artifact due to limited over-time variation in a few explanatory variables. 


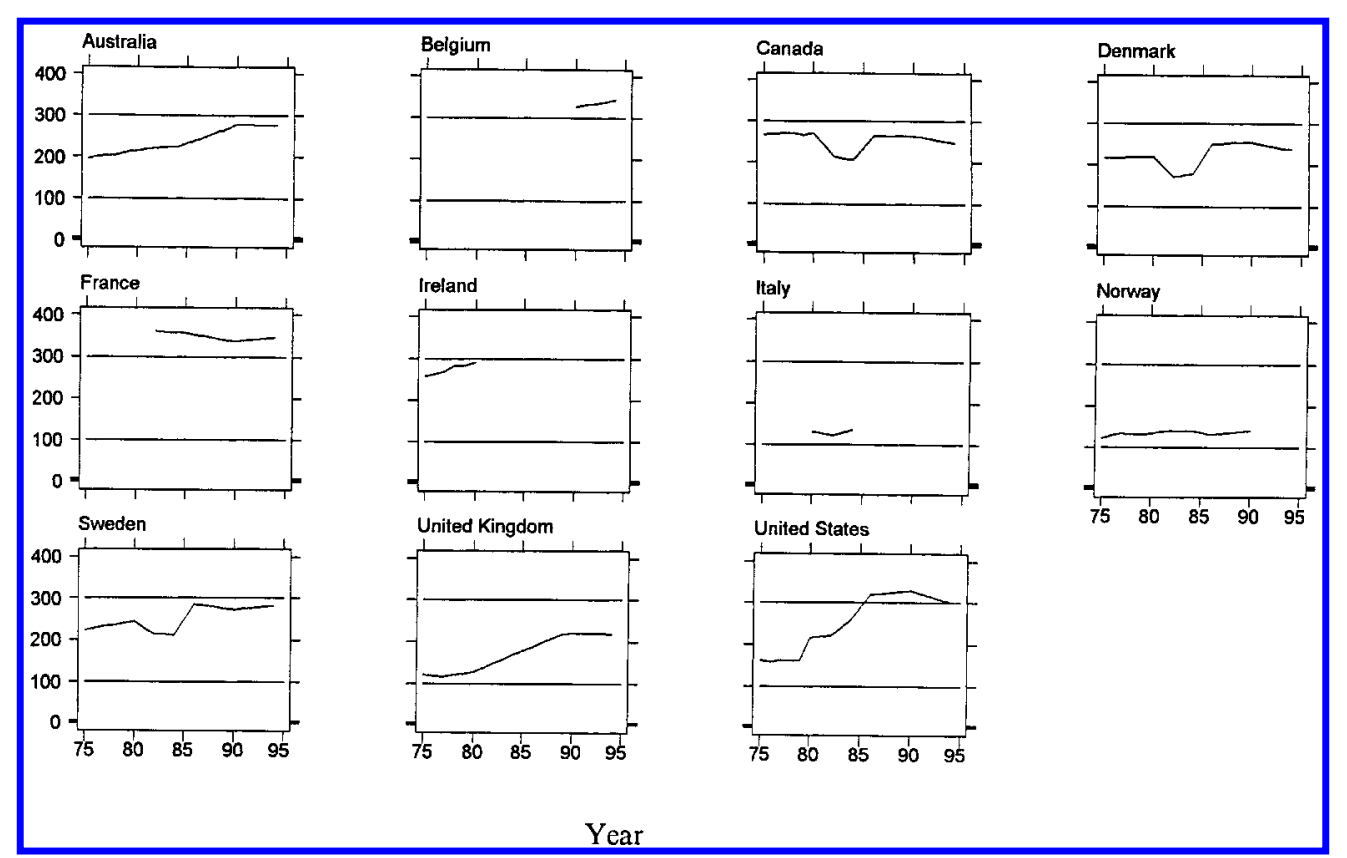

Figure 1 - Police Per Capita Rates by Nation

For this reason, the uncorrected serial correlations (rhos) between residuals are greater than .65. We eliminate this threat to the standard errors by correcting for autocorrelation in all analyses. ${ }^{6}$ Because explanatory variables are lagged and serial correlation is removed, simultaneity bias will not be present.

Figure 1 shows national changes in law enforcement strength. Mean police strength clearly differs between nations, but the separate intercepts in the fixed-effects models will adjust for such contrasts. National trends also differ, but the nation-specific trends included in the models will help eliminate this heterogeneity. The year-specific dummies will capture the recession and any other external time-specific shocks that produced shifts in law enforcement strength across nations. We therefore attack problems with potentially dissimilar data that can bias cross-national results by including exhaustive controls. While these controls substantially enhance comparability by eliminating unmeasured effects and systematic measurement error, this greater confidence in the results comes at a price. Because so many national differences are held constant, we must focus on nomothetic generalities and, with few exceptions, ignore idiosyncratic national experiences even though unique national events undoubtedly contributed to these contrasts in domestic coercive capacity.

6. We analyze the fixed-effects models with the tscorr ARl correction provided by the XTREGAR routine in Stata version 7. The other ARI corrections available in the XTREGAR procedure produce significance tests that have theoretically identical implications. We analyze the only model that does not use fixed-effects with the population-average routine (XTGEE) in Stata. We use an ARl correction for serial correlation and a Huber-White correction for heteroskedasticity. These two choices make the correction for autocorrelation robust to misspecification (Wooldridge 2002), and, in contrast to the ARl procedure in XTREGAR, this ARl procedure does not remove the first panel. 


\section{Explanatory Variables}

Economic inequality is measured with a Gini index computed on incomes. ${ }^{7}$ We assess historically contingent breaks in the relationship between inequality and police strength by following Stephan Haynes and Jacobs (1994) and creating two explanatory variables. The first is calculated with the product of Gini and a dummy variable set equal to 1 from 1974 to 1984 and 0 otherwise, while the second is equal to Gini multiplied by a dummy variable equal to 1 for years after 1984. We choose this time because it represents the end of the world-wide recession when nations had greater opportunities to alter the size of their law enforcement agencies. Each periodized inequality variable will not have a perfect inverse association with its other-period counterpart because inequality scores differed in these periods. We avoid overfitting and reductions in the power of the significance tests by restricting these historically contingent measures to one break located just after this recession.

Ethnic or racial threat is assessed with the percentage of minorities calculated by Ted Gurr (1994). The two-year lag on this variable means we use Gurr's 1992 minority presence scores to predict the final (1994) police per capita rates. To test for American exceptionalism, we include an interaction term equal to a dummy coded 1 for the United States multiplied by minority presence (as minority presence varies over time, this product can have explanatory power in fixed-effects models). We measure joblessness with the total unemployment rate. Social disorganization is assessed with the log of out-of-wedlock birth rates. This variable is in $\log$ (to the base $e$ ) form to reduce the outliers, but, except for modest improvements in regression diagnostics, this transformation has trivial effects. We assess the tax base with GDP per capita in 1990 dollars. To capture the likely increase in police officers after a growth in lawlessness, we include crime rates in log form. We use procedures identical to those outlined above to break these rates into two separate periodized variables. ${ }^{8}$ Finally, urbanization is gauged with the percentage living in cities. Table 1 shows the predicted signs, means, and standard deviations for all variables (see the appendices for national statistics on police strength and the correlation matrix; given the level of aggregation, these correlations are modest).

\section{Specification}

Because the relationships at issue are likely to take longer than a year to be completed, all explanatory variables are lagged by two years, but other plausible lags produce only trivial differences in the results. According to theory, all relationships should be positive, so, except for tests on the intercept, all significance tests are one-tailed. One of the more general specifications of these two-factor fixed-effects models corrected for first-order serial correlation therefore is:

7. Gini (the most common measure of inequality) assesses departures from perfect equality by comparing the cumulative percentages of income received by cumulative percentages of income recipients. In a particular nation, for example, the bottom 20 percent of all families may receive six percent of the total family income, while the bottom 40 percent may receive 14 percent, and the bottom 60 percent may receive perhaps 33 percent. Gini summarizes these departures from perfect equality (where the "bottom" 20 percent would get 20 percent and the "bottom" 40 percent would get 40 percent and so on) with an index that varies incrementally from zero-denoting a completely equal distribution-to unity denoting a perfectly unequal distribution in which one family would receive all income. See Sen (1973) for a clear presentation.

8. Scores for the Gini index were collected from nation-specific sources that are available from the authors on request. Racial composition scores come from Gurr's "Minority at Risk" study. The percentage of unemployed comes from various volumes of the OECD Economic Outlook while GDP figures come from National Accounts Main Aggregates Vol. 1, 1960-1996, 1998 Edition (OECD Publication). Out-of-Wedlock births come from The Canadian World Almanac and Book of Facts: 1987 and the United Nations World Demographic Yearbook. 
Table $1 \cdot$ Expected Signs, Means, and Standard Deviations $(\mathrm{N}=165$ nation-years $)$

\begin{tabular}{|c|c|c|c|}
\hline Variable & Expected Sign & Mean & $\begin{array}{l}\text { Standard } \\
\text { Deviation }\end{array}$ \\
\hline Police per 100,000 & & 233.708 & 66.477 \\
\hline Real per capita $\mathrm{GDP}_{\mathrm{t}-2}{ }^{\mathrm{a}}$ & + & 12.958 & 6.664 \\
\hline$\%$ Minority $_{\mathrm{t}-2}$ & + & 11.825 & 9.566 \\
\hline$\% \operatorname{Urban}_{\mathrm{t}-2}$ & + & 78.999 & 8.588 \\
\hline$\%$ Unemployed $_{\mathrm{t}-2}$ & + & 6.562 & 2.970 \\
\hline Ln out-of-wedlock birth rate ${ }_{t-2}$ & + & 4.605 & 0.503 \\
\hline Inequality $_{\mathrm{t}-2}$ & + & 29.741 & 5.900 \\
\hline Ln crime rate $e_{t-2}$ & + & 8.492 & 5.536 \\
\hline$\%$ Minority $_{\mathrm{t}-2} \times$ U.S. dummy & + & 2.432 & 6.579 \\
\hline
\end{tabular}

${ }^{\mathrm{a}}$ To produce interpretable 4 place regression coefficients, the GDP measure has been divided by 1,000 in this and all subsequent analyses.

$$
\begin{aligned}
& \text { POLICE STRENGTH }_{\mathrm{t}}=\mathbf{b}_{0}+\mathbf{b}_{1} \text { REALCAPGDP }_{\mathrm{t}-2}+\mathbf{b}_{2} \% \text { UNEMPLOYED }_{\mathrm{t}-2}+\mathbf{b}_{3} \% \text { URBAN }_{\mathrm{t}-2} \\
& +\mathbf{b}_{4} \text { NONWEDBIRTHS }_{\text {t-2- }}+\mathbf{b}_{5} \% \text { MINORITY }_{\mathrm{t}-2} \\
& +\mathbf{b}_{6}\left(1 \text { if U.S. } \times \% \text { MINORITY }_{t-2}\right)+\mathbf{b}_{7}\left(\text { INEQUALITY }_{\mathrm{t}-2} \times \text { EARLY }_{\mathrm{t}-2}\right. \\
& +\mathbf{b}_{8}\left(\text { INEQUALITY }_{\mathrm{t}-2} \times \text { LATE }_{\mathrm{t}-2}+\mathbf{b}_{9}\left(\text { CRIMERATE }_{\mathrm{t}-2} \times\right. \text { EARLY }\right. \\
& +\mathbf{b}_{10}\left(\text { CRIMERATE }_{\mathrm{t}-2} \times \text { LATE }\right) \\
& +(\text { NATION-SPECIFIC TRENDS })+(\text { YEAR DUMMY VARIABLES) }(1)
\end{aligned}
$$

with all variables defined as above. The coefficients on the nation-specific trend variables and those on the year or case dummy variables are not reported in the tables, but they are included in all reported fixed-effects models (nation-specific dummies, of course, are omitted in the one random-effects model; complete results that show all coefficients, any analyses mentioned in the text but not shown, and the data are available on request). Note that when we test for interactions, all relevant main effects are included in that dummy variables representing both year and nation are entered each analysis. ${ }^{9}$

\section{Multivariate Pooled Time-Series Cross-Sectional Results}

The results from both fixed- and random-effects population-averaged panel analyses corrected for serial correlation are reported in Table 2. We start with a basic fixed-effects model and include the most obvious explanatory variables-real gross national product per capita, the percentage of minorities, the percentage living in cities, and economic inequality along with (unreported) dummies for year and nation, and nation-specific trend variables. In Model 2 of Table 2 we add the unemployment and out-of-wedlock birth rates. The results suggest that inequality explains police strength, but social disorganization does not. The per capita number of police employees also is unaffected by out-of-wedlock birth rates or by urbanization, and neither crime nor unemployment account for this outcome. Taxable resources as measured by real per capita GDP have no discernable explanatory power as well.

9. Data problems make other controls impossible. Statistics on drug crimes do not seem to exist, while information from within-nation units like states or provinces is available for only a few of these advanced societies. These limitations mean we cannot disaggregate unemployment by age or by gender, and we have not found data on private police. Although data required to test these effects are not available, the extensive controls we do use (nation-specific dummies, nation-specific time trends, and additional year-specific dummies that hold constant any cross-national trends common to all cases) make bias due to omitted variables unlikely. For these and other reasons, removing the three nations with the most missing data (Belgium, Ireland, Italy) has only trivial effects on the results. 
Table 2 - Two-Factor Pooled Time-Series Fixed-Effects or Population-Averaged Models Corrected for Serial Correlation that Explain Police Strength in 11 Nations (coefficients on national dummies, year dummies, and nation-specific time trends are not presented)

\begin{tabular}{|c|c|c|c|c|c|}
\hline Explanatory Variable & 1 & 2 & 3 & 4 & $5^{\mathrm{a}}$ \\
\hline $\begin{array}{l}\text { Per capital real GDP } \\
\quad(\text { divided by } 1,000)_{\mathrm{t}-2}\end{array}$ & $\begin{array}{c}3.2517 \\
(3.2135)\end{array}$ & $\begin{array}{l}3.2329 \\
(3.2367)\end{array}$ & $\begin{array}{l}3.1293 \\
(3.1018)\end{array}$ & $\begin{array}{l}3.8057 \\
(3.0754)\end{array}$ & $\begin{array}{l}-.4152 \\
(1.7763)\end{array}$ \\
\hline$\%$ Minority $_{\mathrm{t}-2}$ & $\begin{array}{l}-8.1317 \\
(15.8372)\end{array}$ & $\begin{array}{l}-8.5447 \\
(16.7309)\end{array}$ & $\begin{array}{l}-9.6829 \\
(16.1842)\end{array}$ & $\begin{array}{l}-9.0412 \\
(15.9436)\end{array}$ & $\begin{array}{c}-9.8671 \\
(9.8220)\end{array}$ \\
\hline$\% \operatorname{Urban}_{t-2}$ & $\begin{array}{r}-18.6211 \\
(15.6724)\end{array}$ & $\begin{array}{r}-18.5527 \\
(15.7617)\end{array}$ & $\begin{array}{r}-24.7098 \\
(15.3490)\end{array}$ & $\begin{array}{r}-22.3512 \\
(15.1133)\end{array}$ & $\begin{array}{r}-4.1563 \\
(6.2671)\end{array}$ \\
\hline$\%$ Unemployed $_{\mathrm{t}-2}$ & - & $\begin{array}{l}-.1360 \\
(1.3319)\end{array}$ & $\begin{array}{l}-.0697 \\
(1.2778)\end{array}$ & $\begin{array}{l}-.0380 \\
(1.2601)\end{array}$ & $\begin{array}{r}-1.2235 \\
(.9666)\end{array}$ \\
\hline $\begin{array}{l}\text { Ln out-of-wedlock } \\
\text { birth rate } \text { t-2 }\end{array}$ & - & $\begin{array}{c}1.0500 \\
(12.9507)\end{array}$ & $\begin{array}{c}2.5200 \\
(13.1295)\end{array}$ & $\begin{array}{c}2.3135 \\
(12.9355)\end{array}$ & $\begin{array}{c}4.4632 \\
(9.1869)\end{array}$ \\
\hline Economic inequality $_{\mathrm{t}-2}$ & $\begin{array}{l}3.0140 * \\
(1.6429)\end{array}$ & $\begin{array}{l}3.0029 * \\
(1.6556)\end{array}$ & - & - & - \\
\hline $\begin{array}{l}\text { Economic inequality } \\
\text { before } 1985_{t-2}\end{array}$ & - & - & $\begin{array}{c}2.6890 \\
(1.6832)\end{array}$ & $\begin{array}{c}2.7982 \\
(1.6613)\end{array}$ & $\begin{array}{l}2.2053 * \\
(1.2920)\end{array}$ \\
\hline $\begin{array}{l}\text { Economic inequality } \\
\text { after } 1984_{t-2}\end{array}$ & - & - & $\begin{array}{l}3.4615^{*} \\
(1.5998)\end{array}$ & $\begin{array}{l}3.3507 * \\
(1.5790)\end{array}$ & $\begin{array}{l}2.7110^{*} \\
(1.2485)\end{array}$ \\
\hline Ln crime rate $\mathrm{t}_{\mathrm{t}-2}$ & $\begin{array}{c}6.2939 \\
(7.6193)\end{array}$ & $\begin{array}{c}6.2688 \\
(7.6600)\end{array}$ & - & - & - \\
\hline $\begin{array}{l}\text { Ln crime rate before } \\
1985_{t-2}\end{array}$ & - & - & $\begin{array}{r}-2.4749 \\
(7.4168)\end{array}$ & $\begin{array}{l}-2.2971 \\
(7.3228)\end{array}$ & $\begin{array}{r}-2.0823 \\
(5.0287)\end{array}$ \\
\hline $\begin{array}{l}\text { Ln. crime rate after } \\
1984_{t-2}\end{array}$ & - & - & $\begin{array}{l}39.3337^{* *} \\
(12.8560)\end{array}$ & $\begin{array}{l}37.3599 * * \\
(12.7184)\end{array}$ & $\begin{array}{l}33.7781^{* * *} \\
(6.4320)\end{array}$ \\
\hline $\begin{array}{l}\text { \% Minority } \text { t-2 } \times \text { U.S. } \\
\text { dummy }\end{array}$ & - & - & - & $\begin{array}{l}182.6325^{*} \\
(90.3078)\end{array}$ & $\begin{array}{l}42.1315^{* * *} \\
(8.6172)\end{array}$ \\
\hline Intercept & $\begin{array}{l}15216.7 * * * \\
(1553.7)\end{array}$ & $\begin{array}{l}15308.1^{* * *} \\
(1583.7)\end{array}$ & $\begin{array}{l}17434.4^{* * *} \\
(1512.6)\end{array}$ & $\begin{array}{c}-37520.7^{* * *} \\
(6188.7)\end{array}$ & $\begin{array}{c}235.719 \\
(546.935)\end{array}$ \\
\hline $\begin{array}{l}\mathrm{R}^{2} \text { (within) or } \\
\text { chi-square }\end{array}$ & $.566^{* * *}$ & $.566^{* * *}$ & $.606^{* * *}$ & $.623 * * *$ & $\begin{array}{l}1338.9 * * * \\
\text { (chi-square) }\end{array}$ \\
\hline Nation-years & 154 & 154 & 154 & 154 & 165 \\
\hline
\end{tabular}

${ }^{a}$ Model 5 is estimated with a population-averaged random-effects approach with robust standard errors and an AR 1 correction for serial correlation. There are 165 nation-years because this ARl correction does not remove the first case in each series.

$* \mathrm{p} \leq .05 \quad * * \mathrm{p} \leq .01 \quad * * * \mathrm{p} \leq .001$ (standard errors are in parentheses; 1-tailed tests except for intercepts).

But we still do not know if the crime rates have stronger effects on the size of law enforcement agencies in the last years of the sample after the politicization of street crime, and we need to find out if the relationship between economic inequality and police strength differs by period. In the next three models, we test for such historically contingent relationships by breaking both economic inequality and the crime rates into two periodized components. Recall that these relationships are tested with the product of economic inequality or the crime rates and two period dummies (we do not split other variables because we find only negligible contrasts). In Models 4 and 5 we enter another interaction term to see if minority presence matters only in the United States. 
In Model 3 we find evidence for both historical contingencies. Although the difference between these coefficients is not significant, the coefficient on economic inequality is stronger in the latter half of the period at issue. This contrast runs counter to what one would expect from post-industrial suggestions that economic inequality has become less important. We find contingent effects for the crime rates because the coefficient on this variable in the latter period is substantially larger than its earlier counterpart, and this difference is statistically significant. In Model 4 we add the interaction that tests the effects of minority presence in the United States and find support for this hypothesis. Because interactions between minority presence and dummy variables for other nations in the sample (not shown in Table 2) do not explain social control capacity, the results suggest that minority threat only accounts for police strength in a nation that had such exceptionally sharp racial conflicts throughout its history.

In Model 5 we use the same variables, but we estimate with a random-effects population-averaged procedure. As cross-sectional variation is greater than over-time variation in some explanatory variables, a fixed-effects approach may underestimate these relationships. If this problem is present, contrasts can be expected when we estimate with a random-effects approach that captures cross-sectional as well as over-time variation. This procedure also lets us correct for heteroskedasticity and serial correlation. All prior results persist, however, so there is no reason to think that modest over-time variation in some variables has distorted the fixed-effects estimates.

A summary of the results suggests that inequality always accounts for police strength, but the prior findings about the positive relationship between minority threat and department size seem to hold only in the United States. Other results show that the relationship between crime and law enforcement strength is historically contingent. Finally, the evidence also does not support post-industrial claims that economic inequality has become less relevant.

\section{Methodological Issues}

In addition to greater generality, there are other reasons to analyze cross-national data. When subgovernments reduce law enforcement spending, they often find that law breakers relocate from areas that spend greater amounts on the police. In the United States, illicit drug manufacturing can rapidly expand in an area after reductions in these expenditures occur. National-level analyses automatically take such regional interdependencies into account, but these effects have not been addressed in the studies based on subgovernments. In all but two of the nations in this analysis, decisions about law enforcement are made by the central government, so an analysis based on national-level data clearly is the most suitable procedure. In the two cases where many decisions about law enforcement are made by subgovernments (Australia and the United States [Terrill 1999]), law enforcement strength nevertheless is based on multilevel processes. ${ }^{10}$ Cross-sectional analyses limited to data from subgovernments within one nation therefore can miss important factors affecting police strength.

Including taxes or welfare payments divided by GDP, the percentage of males aged 15 to 29 , or the political strength of conservative parties does not alter the conclusions, and these variables are not significant. While the divorce and infant mortality rates are plausible measures of disorganization, they do not explain police strength. And employment in service industries has no relationship with this outcome (these relationships are not shown because missing data eliminates many nation years). Time invariant effects like federalism or local control over the police cannot be assessed in fixed-effects models, but the product of a

10. Claims that the changes modeled here are not gradual are contradicted by the data (see Figure 1) and by the vast literature on how public policies are altered incrementally. In the unlikely event that police strength in entire nations did shift by large amounts, such shifts would not invalidate statistical assumptions about random error terms. 
dummy coded 1 for local control and minority presence or an interaction between a federalism dummy and minority presence do not produce significant relationships in additional analyses not shown. While it is unfortunate that data on private police are unavailable, as long as the affluent can shift the costs of their protection to all tax payers, they have less need to purchase such costly services. The robust relationships between inequality and police strength imply that affluent citizens are successful in these cost-shifting efforts, but analyses of private-police spending nevertheless would be useful. Finally, when we included squared terms to test for nonlinear relationships, they were non-significant.

These results are not an artifact of the extensive controls entered in these models. If the nation-specific trends are removed (in analyses not shown), economic inequality continues to account for law enforcement strength. This finding persists when we eliminate the yearspecific dummy variables that capture yearly shocks that affect multiple nations, and the last model shows that the removal of the nation-specific dummy variables does not alter the findings. The results show that only modest changes in the coefficients or the standard errors and no changes in the theoretical implications occur when different explanatory variables are entered. These equivalent findings also persist when we use either fixed- or random-effects estimation. Such stable findings suggest that collinearity is not problematic. The controls for year, nation, and nation-specific time trends make it difficult to believe that the results are biased by unmeasured effects. All of these considerations suggest that we have isolated the major processes that produce differences in the strength of law enforcement agencies in these nations. ${ }^{11}$

\section{Discussion}

Our goal was to see if shifts in economic stratification, minority presence, or unemployment account for law enforcement strength in the most progressive societies. To detect the effects of these potentially destabilizing conditions, we assessed relationships between these divisions and the number of police employees in 11 economically developed nations. To find out if results based on U.S. data that support the minority threat explanation hold in other societies, we assessed the effects of minority presence. Our results offer no evidence that the size of minority populations contributes to law enforcement strength in other advanced nations. These findings and the significant U.S.-minority presence interaction suggest that results that show a positive association between minority presence and police strength across U.S. jurisdictions may be due to intense racial conflicts that did not occur in the other nations in this analysis.

We assessed the explanatory power of economic threat by seeing if economic stratification accounts for national differences in police strength. We find evidence for this association as the findings always indicate that there is a positive relationship between economic inequality and the per capita number of police employees. The period-specific results also offer negative evidence about the post-industrial claims by authors like Robert Nisbet (1959), Daniel Bell (1973), or Seymour Lipset and Terry Clark (1993). Class politics based on economic stratification does not appear to have become less important with the passage of time.

The findings also provide evidence for another interesting historically contingent rela-

11. Although model evaluation based on $\mathrm{R}^{2}$ values is dubious, given the extensive controls included in these analyses, the explanatory power of the reported fixed-effects models is substantial. If we use a more conventional fixedeffects routine that does not correct for serial correlation, we find that the appropriate within $\mathrm{R}^{2} \mathrm{~s}$ (which ignore nationspecific dummies) for the reported fixed-effects models are greater than .85 for Models 1 through 4 in Table 2. The adjusted $\mathrm{R}^{2}$ for the specification used in what probably is the best model (Model 4 of Table 2) that includes case specific dummy effects and all other controls is .975. These contrasts suggest that an absence of corrections for serial correlation in the few published fixed-effects cross-national studies produced inflated estimates of explanatory power. 
tionship. As Garland (2001), Chambliss (1994), and many others have noted, street crime has become a much more salient public concern in many nations where politicians stand for election. Partisan political tactics probably account for this new concern. Conservative politicians have started to use law and order as a "wedge" issue to divide political coalitions that in the past had provided reliable votes for their opponents on the moderate left (Garland 2001; Tonry 2001). This recent politicization of street crime should strengthen the relationship between the crime rates and law enforcement strength in the last half of the period we analyze, and that is what we find.

But these analyses provide no evidence for the most intensely studied relationship in the crime control literature. Unemployment was not related to law enforcement strength. Although theorists (Chambliss 1964; Rusche and Kirchheimer 1939) have focused on incarceration, our findings do not support claims that state control agencies expand after a growth in the supply of excess labor, but almost all of the statistically advanced pooled cross-sectional or time-series analyses find that unemployment does not explain criminal justice outcomes (Jacobs and Carmichael 2001; Jacobs and Helms 1996; Parker and Horwitz 1986; Sutton 2004). Perhaps increasingly liberal unemployment compensation policies have eliminated such effects or perhaps the older studies that found this relationship were based on lessrefined statistical analyses.

The findings also do not support social disorganization hypotheses. Family breakdown does not account for police strength. The out-of-wedlock birth rate, or (in analyses not shown) infant mortality or divorce rates do not explain this outcome, and we find no evidence that taxable resources assessed by real per capita GDP affects police strength. Perhaps these negative findings can be attributed to exhaustive specifications. Because we correct for serial correlation and include formidable controls, nonexistent relationships that might appear to be significant in other studies do not account for police strength in this investigation. ${ }^{12}$

\section{Theoretical Implications}

To resolve basic questions about coercive reactions to conditions that may destabilize domestic order in advanced societies, this study reports the results of a cross-national analysis of the population standardized number of law enforcement employees. The repeated finding that economic inequality accounts for police strength supports conflict accounts based on assertions that the agencies responsible for maintaining domestic order with force primarily protect the affluent. We also find evidence that higher crime rates produce expansions in law enforcement strength, but this relationship appears only in the most recent periods after crime was politicized in many of these nations.

Macro tests of political hypotheses about law enforcement can detect universal relationships, but such analyses typically fail to provide information about the (probably) immeasurable intervening micro-processes that link the macro conditions conferring influence to political outcomes. The links between the societal arrangements that give the affluent greater political influence and the political outcomes that help these prosperous citizens almost always must be inferred. Accurate information about interactions between economic elites and public officials is difficult or impossible to obtain. Perhaps the only way such elite expla-

12. Inspections of residual versus fitted (or predicted) value plots suggest that outliers and other distortions are not present. In sharp contrast to models that omit case-specific dummies, year dummies, or case-specific linear trends, a plot of residual versus fitted values produced by Model 4 in Table 4 shows what appears to be a random cloud of points with no patterns. These desirable results support our hope that the extensive controls we use capture almost all of the systematic variation in police strength. Statistical tests for outliers and overly influential observations using equivalent models that cannot be corrected for serial correlation provide additional reasons to believe that these difficulties also are not present. 
nations for political outcomes can be tested is with circumstantial evidence furnished by research procedures much like the one used in this study.

The relationships uncovered in this investigation, however, need not result only from secret interactions between the affluent and public officials. The influence conferred by economic inequality could give economic elites greater control over public values. Critical theorists (Habermass 1971; Milner 1987) and other scholars (Savelsberg 1994) claim that economic resources enhance the ability of the privileged to control mass beliefs. If this account is correct, public officials may be responding to widespread public desires when they increase the number of law enforcement personnel after expansions in economic inequality. Secret lobbying by the affluent need not be the only link between economic conditions that give the affluent greater political influence and law enforcement strength. If affluent elites are more likely to control the media in unequal societies, this resource could help explain our core finding.

The pooled cross-national design used in this study has wider implications for research on social control. The most theoretically informed literature on these issues highlights the value of a comparative historical approach (Chambliss 1964; Garland 1990; Silver 1966; Thompson 1975). Yet the quantitative researchers who studied conflict or political explanations for social control have largely ignored historical or cross-national evidence. Although some researchers studied historical changes in police strength in one local jurisdiction or in one nation (Jacobs and Helms 1997; Loftin and McDowall 1982), the social divisions that produce changes in police strength in other nations have been almost completely ignored. Crossnational findings that show how the associations between hierarchical social divisions and formal social control are contingent should provide a better fit with the historical and comparative emphasis by the scholars who first directed our attention to these theoretically intriguing issues.

And, as the historical work implies, we find significant historical shifts in relationships in the period we study. Although the evidence is only suggestive, the relationship between economic stratification and police strength may be becoming more substantial during a time when explanatory power of reported crimes also is increasing. Yet these theoretically important contingent relationships would be overlooked if our study had been restricted to analyses of police strength across jurisdictions within a single nation in just one year. By analyzing these outcomes in more than one society, time-series research that detects contingent relationships should give us an increasingly nuanced picture about how these potentially destabilizing conditions produce fluctuations in state social control.

Finally, these results suggest that expansions in minority presence explain law enforcement strength in the United States, but this relationship is not present in the other ten advanced societies in our sample. While such findings support the many studies that found this relationship in cross-sectional analyses restricted to this society, our results suggest that minority threat does not matter as much elsewhere. Such contrasting findings about the influence of racial threat should not be surprising in light of the sharp conflicts about race throughout U.S. history (Myrdal 1944; Tocqueville 1948) that apparently have made racial divisions a far more important explanation for coercive control capacity within this nation. 


\section{Appendix}

Table A1 • National Statistics on the Number of Police Employees Per 100,000 Population

\begin{tabular}{lccccc}
\hline Nation & $\begin{array}{c}\text { Number of } \\
\text { Years }\end{array}$ & $\begin{array}{c}\text { Mean Police } \\
\text { Per Capita }\end{array}$ & $\begin{array}{c}\text { Standard } \\
\text { Deviation }\end{array}$ & Minimum & Maximum \\
\hline Australia & 20 & 238.1 & 29.59 & 195.5 & 278.5 \\
Belgium & 5 & 335.5 & 5.97 & 328.0 & 343.2 \\
Canada & 20 & 253.6 & 20.74 & 207.4 & 271.8 \\
Denmark & 20 & 225.1 & 27.23 & 172.9 & 254.7 \\
France & 13 & 348.8 & 8.10 & 336.7 & 360.2 \\
Ireland & 6 & 274.8 & 13.06 & 258.6 & 290.6 \\
Italy & 5 & 129.3 & 4.92 & 122.5 & 121.4 \\
Norway & 16 & 134.6 & 26.07 & 212.5 & 141.1 \\
Sweden & 20 & 251.2 & 42.57 & 115.0 & 283.3 \\
U.K. & 20 & 171.4 & 67.57 & 157.8 & 220.5 \\
U.S. & 20 & 255.7 & & 329.7 \\
\hline
\end{tabular}

Table A2 • Correlation Matrix (N = 165 nation-years)

\begin{tabular}{|c|c|c|c|c|c|c|c|c|c|}
\hline Variable & 1 & 2 & 3 & 4 & 5 & 6 & 7 & 8 & 9 \\
\hline 1 Police per 100,000 & 1.000 & & & & & & & & \\
\hline 2 Real per capita $\mathrm{GDP}_{\mathrm{t}-2}$ & .444 & 1.000 & & & & & & & \\
\hline $3 \%$ Minority $_{t-2}$ & .366 & .170 & 1.000 & & & & & & \\
\hline $4 \%$ Urban $_{t-2}$ & .011 & .197 & .088 & 1.000 & & & & & \\
\hline $5 \%$ Unemployed $_{\mathrm{t}-2}$ & .358 & .215 & .313 & .086 & 1.000 & & & & \\
\hline \multicolumn{10}{|l|}{6 Ln out-of-wedlock } \\
\hline birth rate ${ }_{t-2}$ & .275 & .602 & -.010 & .381 & .019 & 1.000 & & & \\
\hline 7 Inequality $_{\mathrm{t}-2}$ & -.036 & -.086 & .137 & -.535 & .135 & -.299 & 1.000 & & \\
\hline 8 Ln crime rate t -2 & .313 & .487 & .269 & .458 & .157 & .822 & -.473 & 1.000 & \\
\hline \multicolumn{10}{|l|}{$9 \%$ Minority $_{\mathrm{t}-2} \times$} \\
\hline U.S. dummy & .141 & .103 & .323 & -.202 & .032 & .142 & .732 & -.070 & 1.000 \\
\hline
\end{tabular}

\section{References}

Baumer, Eric, Steven F. Messner, and Richard Rosenfeld. 2003. "Explaining Spatial Variation in Support for Capital Punishment: A Multilevel Analysis." American Journal of Sociology 108:844-75.

Bayley, David H. 1975. "The Police and Political Development in Europe." Pp. 1328-79 in The Formation of National States in Europe, edited by Charles Tilly. Princeton, NJ: Princeton University Press.

- 1985. Patterns of Policing: A Comparative International Analysis. New Brunswick, NJ: Rutgers University Press.

- 1999. "Policing: The World Stage." Pp. 3-12 in Policing Across the World: Issues for the Twenty-first Century, edited by R. I. Mowby. London: UCI Press.

Bell, Daniel. 1973. The Coming of Post-Industrial Society. New York: Basic Books.

$\rightarrow$ Bertrand, Marianne and Sendhil Mullainathan. 2001. "Do People Mean What They Say? Implications for Subjective Survey Data." The American Econonomic Review 91:67-72.

Bittner, Egon. 1990. "The Police on Skid Row: A Study of Peacekeeping." Pp. 30-62 in Aspects of Police Work, edited by Egon Bittner. Boston: Northeastern University Press.

Blalock, Hubert. 1967. Towards a Theory of Minority Group Relations. New York: Capricorn Books.

Blau, Peter. 1964. Exchange and Power in Everyday Life. New York: Wiley.

Block, Fred. 1977. “The Ruling Class Does Not Rule." Socialist Revolution 33:6-28.

$\rightarrow$ Blumer, Herbert. 1958. "Race Prejudice as a Sense of Group Position." Pacific Sociological Review 1:3-7. 
Cao, Liqun and Stephan A. Stack. 2000. “Confidence in the Police Among Industialized Nations." Pp. $71-$ 81 in International Criminal Justice, edited by Delbert Rounds. Boston: Allyn and Bacon.

Chambliss, William J. 1964. "A Sociological Analysis of the Law of Vagrancy." Social Problems 12:6777.

1994. "Policing the Ghetto Underclass: The Politics of Law and Law Enforcement." Social Problems 41:177-94.

Chambliss, William J. and Robert B. Seidman. 1982. Law, Order, and Power. Reading, MA: Addison-Wesley. Chamlin, Mitchell B. 1990. "Determinants of Police Strength in Chicago, 1904-1958." The Sociological Quarterly 31:485-94.

Chevigny, Paul. 1995. The Edge of the Knife. New York: New Press.

Chiricos, Theodore G. and Miriam Delone. 1992. "Labor Surplus and Punishment: A Review and Assessment of Theory and Evidence." Social Problems 39:421-46.

Clark, Gerald. 1975. "What Happens When the Police Strike?" Pp. 440-61 in Criminal Law in Action, edited by William Chambliss. Santa Barbara, CA: Hamilton.

Collins, Randall. 1975. Conflict Sociology. New York: Academic.

Ericson, Richard V. 1982. Reproducing Order: A Study of Police Patrol Work. Toronto, Canada: University of Toronto Press.

— 1989. "Patroling the Facts: Secrecy and Publicity in Police Work." British Journal of Sociology 31:219-49.

Fosset, Mark A. and K. Jill Kiecolt. 1989. "The Relative Size of Minority Populations and White Racial Attitudes." Social Science Quarterly 70:820-35.

Garland, David. 1990. Punishment and Modern Society. Chicago: University of Chicago Press.

- 2000. "The Culture of High Crime Societies." British Journal of Criminology 49:347-75.

- 2001. The Culture of Control. Chicago: University of Chicago Press.

Giddens, Anthony. 1971. The Class Structure of Advanced Societies. New York: Harper Press.

Goode, William J. 1972. "The Place of Force in Modern Society." American Sociological Review 37:50719.

Gurr, Ted R. 1979. “On the History of Violent Crime in Europe and America." Pp. 544-96 in Violence in America: Historical and Comparative Perspectives, edited by Hugh D. Graham and Ted R. Gurr. Beverly Hills, CA: Sage Publications.

- 1994. "Group Discrimination and Separatism." Center for International Development and Conflict Management. University of Maryland, College Park, MD.

Habermass, Jurgen. 1971. Knowledge and Human Interests. Boston, MA: Beacon.

Haynes, Stephen E. and David Jacobs. 1994. "Macroeconomics, Economic Stratification, and Partisanship." American Journal of Sociology 100:70-103.

Hout, Michael, Clem Brooks, and Jeff Manza. 1993. "The Persistance of Class in Post-Industrial Societies." International Sociology 8:259-77.

Jackson, Pamela I. 1984. "Opportunity and Crime: A Function of City Size." Sociology and Social Research 69:172-93.

- 1 1989. Minority Group Threat, Crime, and Policing: Social Context and Social Control. New York: Praeger.

Jacobs, David. 1979. "Inequality and Police Strength: Conflict Theory and Coercive Control in Metropolitan Areas." American Sociological Review 44:913-25. 70.

Jacobs, David and Jason T. Carmichael. 2001. "The Politics of Punishment across Time and Space: A Pooled Time-Series Analysis of Imprisonment Rates." Social Forces 80:61-89.

Jacobs, David and Ronald Helms. 1996. "Towards a Political Model of Incarceration: A Time-Series Examination of Multiple Explanations for Prison Admission Rates." American Journal of Sociology 102:323-57.

_. 1997. "Testing Coercive Explanations for Order: The Determinants of Law Enforcement Strength Over Time." Social Forces 75:1361-92.

— 1999 "Collective Outbursts, Politics, and Punitive Resources: Toward a Political Sociology of Spending on Social Control." Social Forces 77:1497-524.

Johnston, Jack and John DiNardo. 1997. Econometric Methods. New York: McGraw Hill.

Joutsen, Matti. 2000. “Comparing Criminal Justice Systems." Pp. 272-87 in International Criminal Justice, edited by Delbert Rounds. Boston: Allyn and Bacon. 
Lenski, Gerhard. 1966. Power and Privilege. New York: McGraw-Hill.

Lindblom, Charles E. 1977. Politics and Markets. New York: Basic Books.

Lipset, Seymour M. and Terry M. Clark. 1993. "Are Social Classes Dying?" International Sociology 8:397410.

Liska, Allen E., Mitchell B. Chamlin, and Mark D. Reed. 1984. "Testing the Economic Production and Conflict Models of Crime Control." Social Forces 64:119-38.

Liska, Allen E., Joseph J. Lawrence, and Michael Benson. 1981. "Perspectives on the Legal Order: The Capacity for Social Control." American Journal of Sociology 87:412-26.

Lizotte, Allan, James J. Mercy, and Eric Monkonen. 1982. "Crime and Police Strength in an Urban Setting: Chicago, 1947-1970." Pp. 129-48 in Quantitative Criminology: Innovations and Applications, edited by John Hagan. Beverly Hills: Sage.

Loftin, Colin and David McDowall. 1982. "The Police, Crime, and Economic Theory: An Assessment." American Sociological Review 47:393-401.

Maguire, Edward R. and Rebecca Schulte-Murray. 2001. "Issues and Patterns in the Comparative International Study of Police Strength." International Journal of Conparative Sociology 42:75-100.

Manly, John. 1983. “Neo-Pluralism: A Class Analysis of Pluralism I and Pluralism II." American Political Science Review 77:368-83.

Manning, Peter K. 1994. "The Police: Symbolic Capital, Class, and Control." Pp. 80-99 in Inequality, Crime, $\theta$ Social Control, edited by George S. Bridges and Martha A. Meyers. Boulder, CO: Westview Press.

McDowall, Donald and Colin Loftin. 1986. "Fiscal Politics and the Police." Social Forces 65:162-76.

Milner, Murray. 1987. "Theories of Inequality." Social Forces 65:1053-89.

Myrdal, Gunnar. 1944. An American Dilemma: The Negro Problem and Modern Democracy. New York: Harper and Brothers.

Nisbet, Robert. 1959. "The Decline and Fall of Social Class." Pacific Sociological Review 2:11-17.

Olson, Mancur. 1965. The Logic of Collective Action. New York: Schocken.

Papke, Lesley E. 1994. "Tax Policy and Urban Development: Evidence from the Indiana Enterprise Zone Program." Journal of Public Economics 54:37-49.

Parker, Robert Nash and Allan V. Horwitz. 1986. "Unemployment, Crime, and Imprisonment: A Panel Approach." Criminology 24:751-73.

Quillian, Lincoln and Devah Pager. 2001. “Black Neighbors, Higher Crime? The Role of Racial Stereotypes." American Journal of Sociology 107:717-67.

Rounds, Delbert. 2000. International Criminal Justice. Boston: Allyn and Bacon.

Rubenstein, Jonathan. 1973. City Police. New York: Farrar, Straus, and Giroux.

Rusche, Georg and Otto Kirchheimer. 1939. Punishment and Social Structure. New York: Russell and Russell.

Sampson, Robert J. 1987. “Urban Black Violence." American Journal of Sociology 93:348-82.

Sampson, Robert J. and W. Byron Groves. 1989. "Community Structure and Crime: Testing Social Disorganization Theory." American Journal of Sociology 94:774-802.

Savelsberg, Joachim J. 1994. "Knowledge, Domination, and Criminal Punishment." American Journal of Sociology 99:911-43.

Sen, Amartya. 1973. On Economic Inequality. New York: Norton.

Sherman, Lawrence. 1992. "Attacking Crime: Policing and Crime Control" Pp. 159-230 in Modern Policing, edited by Michael Tonry and Norval Morris. Chicago: University of Chicago Press.

Silver, Alan. 1966. "The Demand for Order in Civil Society." Pp. 1-24 in The Police: Six Sociological Essays, edited by David Bordua. New York: Wiley.

Stinchcombe, Arthur L. 1968. Constructing Social Theory. New York: Harcourt, Brace and World.

Sutton, John R. 2004. "The Political Economy of Imprisonment in Affluent Western Democracies, 19601990." American Sociological Review, forthcoming.

Tanur, Judith M. 1992. Questions about Questions: Inquiries into the Cognitive Basis of Surveys. New York: Russell Sage.

Taylor, Marylee C. 1998. "How White Attitudes Vary with the Racial Composition of Local Populations: Numbers Count." American Sociological Review 63:512-35.

Terrill, Richard J. 1999. World Criminal Justice Systems. Cincinnati, OH: Anderson.

Thompson, Edward P. 1975. Whigs and Hunters. London: Penguin.

Tilly, Charles. 1984. "War Making and State Making as Organized Crime." Pp. 169-91 in Bringing the State Back In, edited by Peter B. Evans, Dietrich Rueschemeyer, and Theda Skocpol. New York: Cambridge University Press. 
1992. Coercion, Capital, and European States, AD 990-1992. Cambridge, MA: Blackwell.

Tocqueville, Alexis de. 1948. Democracy in America. New York: Knopf.

Tonry, Michael. 2001. Penal Reform in Overcrowded Times. New York: Oxford University Press.

Weber, Max. 1968. Economy and Society. Berkeley: University of California Press.

White, William. 1965. A Puritan in Babylon: The Story of Calvin Coolidge. New York: Capricorn Books.

Wilson, James Q. 1971. Varieties of Police Behavior. New York: Atheneum.

Wooldridge, Jeffrey M. 2002. Econometric Analysis of Cross Section and Panel Data. Cambridge, MA: MIT Press.

Ziliak, James P., David N. Figlio, Elizabeth E. Davis, and Laura S. Connelly. 1999. “Accounting for the Decline in AFDC Case Loads." Journal of Human Resources. 35:570-86. 